\title{
Рост ультратонкой популяции коллоидных нанолистов CdSe с УФ люминесценцией
}

\author{
Д.А. Куртина ${ }^{1)}$, А. В. Гаршев ${ }^{2)}$, Р. Б. Васильев ${ }^{3)}$ \\ ${ }^{1}$ Московский Государственный Университет им.М.В.Ломоносова, \\ Москва, 119991, Ленинские горы \\ тел:+7 (915) 152-0917, эл.nочта: kurtinadaria@gmail.com
}

DOI 10.34077/RCSP2019-109

Двумерные (2D) полупроводники обладают уникальными электронными и оптическими свойствами, возникающими из-за атомно-тонкой толщины и двумерной электронной структуры. Изменяя размер таких частиц, можно контролировать длину волны люминесценции и поглощения, что представляет не только фундаментальный, но и практический интерес. Среди возможных сфер применения можно выделить солнечные элементы, катализ, оптоэлектронику и т.п. В настоящей работе мы впервые вырастили и изучили структуру и свойства атомно-тонких нанолистов $\mathrm{CdSe}$ со спектральным положением экситонных полос 396 нм. Данные квазидвумерные наночастицы интересны благодаря чрезвычайно узким полосам поглощения и люминесценции и иначе называются коллоидными квантовыми ямами (quantum wells) [1,2].

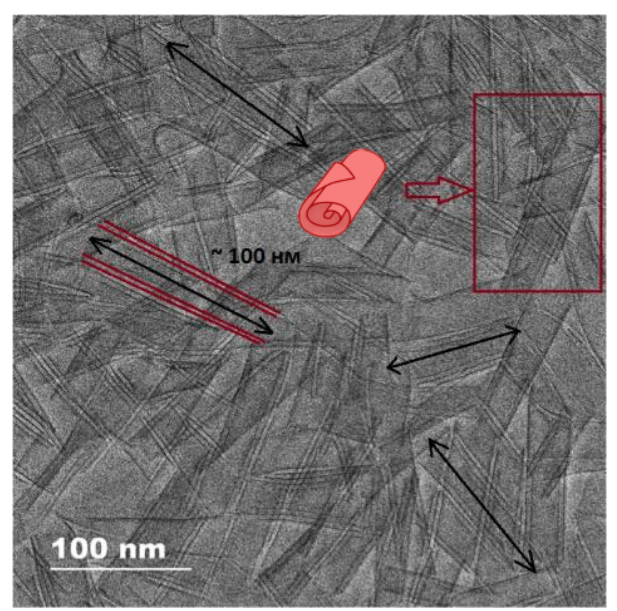

Изображения ПЭМ полученных наночастиц CdSe.

В рамках данной работы впервые были разработаны условия препаративного синтеза квазидвумерных наночастиц CdSe в системе октадецен - ацетат кадмия - олеиновая кислота в атмосфере аргона при температурах роста $110-160^{\circ} \mathrm{C}$ с использованием триоктилфосфинселенида в качестве прекурсора селена. Получены квазидвумерные наночастицы $\mathrm{CdSe}$ с длиной волны первого экситонного максимума 396 нм. Температурная зависимость роста была проанализирована с использованием спекторскопии поглощения. Путем тщательного подбора условий синтеза удалось избавиться от примесной популяции с длиной волны первого экситонного максимума 463 нм. Была предложена методика последовательного увеличения латеральных размеров нанолистов с прецизионным сохранением толщины. Были получены нанолисты с латеральным размером до 1 мкм со строго фиксированной толщиной 2 монослоя. По данным электронной микроскопии была установлена морфология полученных наночастиц, которые представляют собой многократно свернутые прямоугольные листы, а так же был рассчитан их приблизительный латеральный размер, который составил 150 нм для одностадийного синтеза и до 1 мкм для многостадийного. Исходя из данных рентгеновской дифракции, был сделан вывод, что полученные наночастицы обладают структурой цинковой обманки c тетрагональным искажением. Проанализированы оптические свойства синтезированных наночастиц, показавшие наличие узких экситонных полос поглощения и люминесценции с длиной волны 396 нм и шириной порядка 10 нм.

Таким образом в настоящей работе были достигнуты цели по разработке условий препаративного синтеза квазидвумерных наночастиц на основе CdSe и изучению уникальных свойств полученных образцов, которые, благодаря своим узким полосам люминесценции и высокой чистоте света, могут найти широкое применение в оптоэлектронике.

Работа выполнена при поддержке грантов РФФИ 16-29-11694 и 19-03-00481.

\section{Лumepamypa}

[1] R.B.Vasiliev et.al. // Phys. Rev. B, 2017, 95, 165414.

[2] M. Nasilowski et al. // Chem. Rev. 2016, 116, 10934. 